\title{
THE INTERNATIONAL CALENDAR
}

LYONETTE LOUIS-JACQUES*

\section{1}

\section{American Society of Information Science and Technology (ASIST)}

ASIS Summit 2001: "Practicing Information Architecture"

[information architecture, human-computer interaction, visual design, experience design, and usability]

Hyatt Regency San Francisco Airport

February 2-4, 2001

Website: http://www.asis.org/Conferences/Summit2001/

\section{United Kingdom Online Users Groups (UKOLUG)}

"Data Protection and the Other Current Legal Issues in Information Work" [this one-day UKOLUG course will focus on the new framework for data protection and privacy in the United Kingdom; the course will provide basic, but thorough, foundations in a number of current legal issues in information work of concern to all information professionals; course documentation will be provided, together with an essential bibliography and a range of quality legal resources freely available on the Internet;

* Foreign and International Law Librarian and Lecturer in Law, D'Angelo Law Library, University of Chicago Law School.

The compiler welcomes news and information on conferences and other meetings of interest to all IALL members. Please contact her via email at llou@midway.uchicago.edu or letter at D'Angelo Law Library, University of Chicago School of Law, 1121 E. 60 ${ }^{\text {th }}$ St., Chicago, IL 60637, U.S.A.; tel: (773) 702-9612; fax: (773) 702-2889.

The closing date for this column was January 15, 2001. For up-to-date information, check the Calendar at the IALL website at http://www.iall.org. 
Course Leader: Laurence W. Bebbington (University of Nottingham); registration deadline: 1 February 2001]

The Novartis Foundation, 41 Portland Place, London W1N 4BN

February 8, 2001

Website: http://www.ukolug.org.uk/meetings/data.htm http://www.ukolug.org.uk/meetings/meetings.htm

\section{United Kingdom Centre for Legal Education (UKCLE)}

"E-legal Information: Accessing Legal Information for Teaching"

[the seminar brings together leading experts in legal information systems to consider the recent revolutionary developments in the availability, range and quality of electronic legal information systems; the key questions for this seminar are whether such electronic legal information systems are meeting the needs of the legal education community, and the steps necessary to enable lecturers, librarians and students to make effective use of such systems]

Radcliffe House, University of Warwick, Coventry, England

February 12, 2001

Contact: Hansa Surti

Tel: $\quad 02476523117$

E-mail: h.surti@warwick.ac.uk

Website: http://www.ukcle.ac.uk/

\section{West Group}

The $6^{\text {th }}$ Annual Information Innovator's Institute 2001

[will cover law firm technology, knowledge management, intranets, portals, and models for management of library and information systems functions; application deadline, December 20, 2000]

La Playa Beach Resort, Naples, Florida

March 8-10, 2001

Website: http://www.westgroup.com/librarians/iii/iii2001.htm

\section{European Information Association (EIA)}

"EU Database Update"

[databases covered will include EUR-Lex, PreLex, ARCHISplus, ADAM, and a range of others, including the newly released Celex Expert Service]

London, UK

March 12, 2001

Website: http://www.eia.org.uk/eiaorg/train.htm 
International Library Information and Analytical Center (ILIAC) and the American Councils for International Education (ACIE: ACTR/ACCELS) $4^{\text {th }}$ Annual International Workshop on "Electronic Resources and International Information Exchange: East-West": "Digital Resources and Digital Libraries: Opportunities for Cooperation"

[covers legal, ethical and security problems of digital information] Washington, D.C.

March 12-13, 2001

Contact: ILIAC US Office, 1776 Massachusetts Avenue, NW, Suite 700 Washington, D.C. 20036

Tel: (202) 463-7566; (202) 463-7567

Fax: (202) 463-7582

E-mail: iliac@iliac.org; or

ILIAC Russian Office, GPNTB, 12 Kuznetsky most, Moscow, 103919, Russia

Tel: $\quad+7-095-923-4124 ;+7-095-925-4964$

Fax: $\quad+7-095-921-9862$

E-mail: mo@iliac.ru

Website: http://www.iliac.org/

http://www.iliac.ru/

\section{United Kingdom Centre for Legal Education (UKCLE)}

"E-Legal Learning: On the Web"

[this workshop will explore approaches to legal education which make full use of the web's utility to enhance communication, particularly through the use of simulated negotiation between teams of lawyers]

University of Lancaster, UK

March 14, 2001

Website: http://www.ukcle.ac.uk/

\section{American Bar Association (ABA)}

ABA Techshow 2001: "A Legal Technology Odyssey: Making Your Investment Pay!"

[programs include "The Cybrarian - Evolving Roles of the Law Library," "60 Hot Legal PC Tips and Netsites in 60 Minutes," and

"Free and Fee - Hottest Legal Research Resources"]

Chicago, Illinois

March 15-17, 2001

Website: http://www.techshow.com/

http://www.abanet.org/techshow/home.html 


\section{European Information Association (EIA)}

Annual Conference and AGM: "The Information Challenge of the Wider Europe"

[UK's Minister for Europe, Keith Vaz, will speak on the subject of enlargement, plus a range of speakers who have been involved in very practical information projects with countries applying to join the EU]

London, UK

March 26, 2001

Website: http://www.eia.org.uk/eiaorg/train.htm

Information Today, Inc.

Internet Librarian International

London, England

March 26-28, 2001

Website: http://www.internet-librarian.com/

LEXIS Publishing Librarian Relations Group in conjunction with the American Association of Law Libraries (AALL)

Technology Toolkit for Information Professionals (TTIP)

[venues include Atlanta, Chicago, Dallas, Washington, D.C., Los Angeles, Minneapolis, New York, Seattle]

Spring (April-May 2001) and Fall (September-October 2001) Series

Website: http://infopro.lexis.com/events/ttipinfo.htm

International Law Students Association (ILSA)

2001 Philip C. Jessup International Law Moot Court Competition: "The Case Concerning the Seabed Mining Facility"

Washington, D.C.

April 1-7, 2001

Contact: ILSA, 1615 New Hampshire Avenue, NW,

Washington, D.C. 20009

Tel: (202) 299-9101; Fax: (202) 299-9102

E-mail: ilsa@iamdigex.net

Website: http://www.ilsa.org/

\section{American Society of International Law (ASIL)}

95 $5^{\text {th }}$ Annual Meeting: "The Visible College of International Law"

Washington, D.C.

April 4-7, 2001

Contact: Sandra Liebel, 2223 Massachusetts Ave., N.W., Washington, D.C. $20008-2864$ 
Phone: (202) 939-6000; Fax: (202) 797-7133

E-mail: sliebel@asil.org

Website: http://www.asil.org/

http://www.asil.org/schmtg.htm

Association des bibliothèques juridiques suisses - Vereinigung der juristischen Bibliotheken der Schweiz

Annual Meeting: "Paper vs. Electronic Resources"

[electronic periodicals (access, licensing, etc.), access to European documentation resources; languages of meeting are primarily French and German]

Neuchâtel, Switzerland

April 6-7, 2001

Contact: Jarmila Looks (Ms.), Head of the Library, Swiss Institute of Comparative Law, CH-1015 Lausanne - Dorigny

Phone: +41 (0) 2169249 11; Fax: +41 (0) 216924949

E-mail: Jarka.Looks@isdc-dfjp.unil.ch

Website: http://www-isdc.unil.ch/

\section{Infonortics}

The $6^{\text {th }}$ Search Engines Meeting: "Search Engines: Diversity and Controversy"

Fairmont Copley Plaza Hotel, Boston, Massachusetts

April 9-10, 2001

Website: http://www.infonortics.com/searchengines/index.html http://www.infonortics.com/searchengines/sh01/sh01pro.html

\section{LEXIS Publishing Librarian Relations Group}

Advanced Management in Private Law Libraries Conference (AMPLL)

[application deadline December 15, 2000; open to all law librarians working in a management position, such as library manager, director, or department head in a private law firm or corporate legal department]

Scottsdale Conference Resort, Scottsdale, Arizona

April 20-22, 2001

Website: http://infopro.lexis.com/events/ampll2001info.htm

Association of Austrian Librarians (Vereinigung Österreichischer Bibliothekarinnen und Bibliothekare (VÖB)

$9^{\text {th }}$ Österreichisches Online-Informationstreffen $/ 10^{\text {th }}$ Österreichischer

Dokumentartag 
[covers content management of electronic journals, EU projects, ecommerce, information services]

Graz, Universität, Universitätsplatz 3, Austria

April 24-27, 2001

Website: http://www.voeb.uibk.ac.at/odok2001/

Section of International Law and Practice, American Bar Association (ABA)

Spring Meeting

Washington, D.C.

April 25-28, 2001

Website: http://www.abanet.org/intlaw/meet/home.html

Online Inc.

Intranets 2001: “Managing Content, Building Applications, Designing Portals"

Santa Clara Convention Center, Santa Clara, CA

April 30-May 2, 2001

Website: http://www.intranets2001.com/

http://www.onlineinc.com/

\section{University of London, Birkbeck College}

$9^{\text {th }}$ Study Trip

[to observe the United Nations Committee against Torture and the United

Nations Committee on Economics, Social and Cultural Rights holding country headings in Geneva; open to non-college members]

May 7-11, 2001

Contact: Bernard F. Hamilton, President, Leo Kuper Foundation

Tel: $\quad 44$ (0) 20737373 32; Fax: 44 (0) 2073410050

E-mail: Bernie@west-end.demon.co.uk

\section{Caribbean Association of Law Libraries (CARALL)}

Annual General Meeting

Grenada

May 14-17, 2001

Contact: CARALL, c/o Faculty of Law Library, University of the West Indies, P.O. Box 64, Bridgetown, Barbados, West Indies 
The International Association for Social Science Information Services and Technology (IASSIST) and the International Federation of Data Organizations (IFDO)

$27^{\text {th }}$ Annual IASSIST/IFDO Conference: "A Data Odyssey"

[brings together data professionals, data producers, providers, and users from all around the world who are engaged in the creation, acquisition, processing, maintenance, distribution, preservation, and use of numeric social science data for research and instruction]

Amsterdam, The Netherlands

May 14-19, 2001

Website: http://www.niwi.knaw.nl/ia2001.htm

http://www.niwi.knaw.nl/us/ia2001/home.htm

http://www.datalib.library.ualberta.ca/iassist/

Information Today, Inc. and the Special Libraries Association (SLA)

$22^{\text {nd }}$ Annual National Online Meeting \& IOLS 2001

New York Hilton \& Towers

May 15-17, 2001

Website: http://www.infotoday.com/nom2001/default.htm

Information Resources Management Association (IRMA)

2001 IRMA International Conference: "Managing Information Technology in a Global Economy"

Toronto Marriott-Eaton, Toronto, Ontario, Canada

May 20-23, 2001

Website: http://www.irma-international.org/

International Association for Artificial Intelligence and Law, Inc. (IAAIL) ICAIL 2001: Eighth International Conference on Artificial Intelligence and Law

St. Louis, Missouri, USA

May 21-25, 2001

Website: http://www.cs.wustl.edu/icail2001/

http://ais.gmd.de/iaail/icail/icail.html

http://borneo.gmd.de/iaail/iaail.html

Canadian Association of Law Libraries/Association canadienne des Bibliothèques de Droit

CALL/ACBD Annual General Meeting 2001: "Flexing the Right Muscle" London, Ontario, Canada

May 27-30, 2001 
Website: http://www.callacbd.ca/

\section{Washington College of Law, American University}

Summer 2001: "Academy on Human Rights and Humanitarian Law"

[general and specialized courses in English and Spanish; visits to IGOs and NGOs; workshops, conferences, and career panels]

Washington, D.C.

May 29-June 15, 2001

Contact: Tel: (202) 274-4070; Fax: (202) 274-4198

E-mail: hracademy@wcl.american.edu

Website: http://www.wcl.american.edu/pub/humright/hracademy/

\section{European Community Studies Association (ECSA)}

Annual Meeting: "Globalization, European Integration, and Domestic Transformation"

Madison, Wisconsin

May 31-June 2, 2001

Website: http://www.ecsa.org/conf2001.html

Arbeitsgemeinschaft für juristisches Bibliotheks- und Dokumentationswesen (AjBD)

"Internet für juristische Bibliothekare"/“Internet for Law Librarians"

Rostock, Germany

June 2001

Website: http://www.ajbd.de/veranst.htm

British and Irish Association of Law Libraries (BIALL)

$32^{\text {nd }}$ Annual Study Conference and Exhibition: "Keeping the Customer Satisfied: The Delivery of Legal Information"

Silversprings Moran Hotel, Tivoli, Cork, Ireland

June 8-11, 2001

Website: http://www.biall.org.uk/

http://www.biall.org.uk/cork2001.htm

\section{Special Libraries Association (SLA)}

92 ${ }^{\text {nd }}$ SLA Annual Conference: “2001, An Information Odyssey: Seizing the Competitive Advantage"

[Includes programs of their Legal Division and the "International Law Roundtable“]

San Antonio, Texas

June 9-14, 2001 
Website: http://www.sla.org/conf/2001 conf/index.html

\section{American Library Association (ALA)}

\section{ALA Annual Conference}

[includes programs of the International Relations Round Table (IRRT) and the International Documents Task Force (IDTF) of the Government Documents Round Table (GODORT), and the Slavic and East European Section (SEES) and Western European Specialists Section (WESS) of the Association of College and Research Libraries (ACRL), a division of ALA]

San Francisco, California

June 14-20, 2001

Website: $h t t p: / / w w w . a l a . o r g / e v e n t s /$

http://www.ala.org/cro/cal.html

The Academic Council on the United Nations System (ACUNS)

2001 ACUNS Annual Meetings: "Strategies for Sustainable Development and the Pressures of Globalization"

La Universidad de las Américas-Puebla, Puebla, Mexico

June 15-17, 2001

Website: http://www.yale.edu/acuns/

\section{European Institute of Public Administration (EIPA)}

Seminar: "Who's Afraid of European Documentation?"

Maastricht, The Netherlands

June 18-20, 2001

Website: http:/www.eipa.nl/

\section{Center for Computer Assisted Legal Education (CALI)}

$11^{\text {th }}$ Annual Conference for Law School Computing

Suffolk University Law School, Boston, Massachusetts

June 21-23, 2001

Website: http://www.cali.org/conference/2001/index.html

Comparative Interdisciplinary Studies Section (CISS) of the International Studies Association (ISA)

CISS/ISA Third International Millennium Series Conference: “Assessing and Responding to Policy Imperatives for a Complex World: Global, Regional, National, and Local Dimensions"

Heidelberg, Germany

June 25-26, 2001 
Website: http://csf.colorado.edu/isa/CISS-Section/index.htm http://csf.colorado.edu/isa/future-conf.html http://www.isanet.org/

Organisation of South African Law Libraries (OSALL) - Organisatie van Suid-Afrikaanse Regsbiblioteke (OSAR)

Annual General Meeting

July 2001

Website: http://sunsite.wits.ac.za/osall/

\section{American Association of Law Libraries (AALL)}

94 ${ }^{\text {th }}$ Annual Meeting and Conference 2001: "New Realities, New Roles"

[includes educational programs of AALL's Foreign, Comparative, and International Law Special Interest Section (FCIL SIS) and the AsianAmerican Law Librarians Caucus (AALLC), and the FCIL SIS Reception for Attendees from Abroad and the International Association of Law Libraries (IALL) reception]

Minneapolis, Minnesota

July 14-19, 2001

Website: http://www.aallnet.org/events/

\section{International Studies Association (ISA)}

2001 Hong Kong International Convention: "Globalization and Its Challenges in the $21^{\text {st }}$ Century"

Hong Kong

July 26-28, 2001

Contact: Steve Chan, 2001 Hong Kong Convention Coordinator, Department of Political Science, Campus Box 333, University of Colorado, Boulder, CO 80309-0333

Fax: (303) 492-0978

E-mail: steve.chan@colorado.edu

(You can also contact ISA Headquarters at (520) 621-7715 or isa@u.arizona.edu)

Website: http://csf.colorado.edu/isa/hongkong/

http://www.isanet.org/

\section{American Bar Association (ABA)}

Annual Meeting

[includes programs of the Section of International Law and Practice] Chicago, Illinois

August 2-8, 2001 
Website: http://www.abanet.org/annual/2001/home.html http://www.abanet.org/events.html

The Academic Council on the United Nations Systems (ACUNS) and the American Society of International Law (ASIL)

2001 ACUNS/ASIL Summer Workshop on International Organization Studies [application deadline is January 15, 2001]

University of Namibia, Winhock, Namibia

August 5-18, 2001

Website: http://www.yale.edu/acuns/

International Federation of Library Associations and Institutions (IFLA) 67 $7^{\text {th }}$ IFLA Council and General Conference: "Libraries and Librarians: Making a Difference in the Knowledge Age"

Boston, Massachusetts, USA

August 16-25, 2001

Website: http://www.ifla2001.org/ http://www.ifla.org/IV/ifla67/index.htm

http://www.aallnet.org/prodev/ifla2001.asp

Australian Library and Information Association (ALIA) Special Libraries Section and Health Libraries Section and Australian Law Librarians' Group (ALLG)

$9^{\text {th }}$ Special, Health and Law Libraries Conference: "Rivers of Knowledge"

[Includes the biennial general meeting of the Australian Law Librarians' Group]

Melbourne, Australia

August 26-29, 2001

Contact: Conference Organizer, Trevor Wakely

Tel: +61 39669 4301; Fax: +61396694611

E-mail: t.wakely@bom.gov.au

Website: http://www.alia.org.au/conferences/2001.html

http://www.allg.asn.au/

http://www.alia.org.au/conferences/shllc/2001/

\section{American Political Science Association (APSA)}

$97^{\text {th }}$ Annual Meeting

[includes panels on Comparative Politics, International Political Economy, International Security and Arms Control, International History and Politics, (U.S.) Domestic Sources of Foreign Policy, and International Relations] 
San Francisco, CA

August 30-September 2, 2001

Website: http://www.apsanet.org/mtgs/index.cfm http://PRO.harvard.edu/

Standing Group on International Relations, European Consortium for Political Research (ECPR)

$4^{\text {th }}$ Pan-European International Relations Conference

University of Kent, Canterbury, U.K.

September 18-20, 2001

Website: http://www.essex.ac.uk/ecpr/genconf/2001_IR.htm

International Association of Law Libraries (IALL)

$20^{\text {th }}$ Annual Course on International Law Librarianship: "Comparative and International Law in Multilingual Context"

Swiss Institute of Comparative Law, Lausanne, Switzerland

September 23-26, 2001

Contact: IALL, Marie-Louise Bernal, P.O. Box 5709, Washington, D.C. 20016

Fax: (202) 707-1820

Website: http://www.iall.org/

http://www.iall.org/conf.htm

American Branch of the International Law Association (ILA)

International Law Weekend 2001

New York, NY

October 2001

Website: http://www.ambranch.org/

http://www.ambranch.org/2001Weekend.htm

Canadian Council on International Law (CCIL)/Counseil canadien de droit international (CCDI)

Annual Conference

Ottawa, CA

October 2001

Website: http://www.ccil-ccdi.cal

\section{Asser College Europe}

Training Course for Legal Information Specialists

[application deadline is June 30, 2001]

October/November 2001 
Website: http://www.asser.nl/educatio/indxedu.htm

http://www.asser.nl/educatio/acelib.htm

Online Inc.

Internet Librarian 2001

Pasadena Conference \& Exhibition Center, California

November 6-8, 2001

Website: http://www.online.com/

Online Inc.

EContent 2001: The Content Expo

Santa Clara Convention Center, Santa Clara, California

November 12-13, 2001

Website: http://www.econtent2001.com/

http://www.onlineinc.com/

European Institute of Public Administration (EIPA) and the European Information Association (EIA)

Seminar: "Keep Ahead with European Information"

[international conference on advanced aspects of EU information retrieval, storage and access]

Maastricht, The Netherlands

November 19-20, 2001

Website: http://www.eipa.nl/

http://www.eia.org.uk/eiaorg/train.htm

2002

International Studies Association (ISA)

Annual Conference

New Orleans, LA

March 24-28, 2002

Website: http://csf.colorado.edu/isa/isaconf.html

American Association of Law Libraries (AALL), Australian Law Libraries Group (AALG), British and Irish Association of Law Libraries (BIALL), and Canadian Association of Law Libraries/Association canadienne des Bibliothèques de Droit (CALL/ACBD)

The $3^{\text {rd }}$ Joint Study Institute

May 22-24, 2002 
Royal Roads University, Victoria, British Columbia, Canada

Contact: Institute Chairperson, Suzan A. Hebditch, Regional Law Librarian, Canada Department of Justice

Voice: (780) 495-2973; Fax: (780) 495-2964

E-mail: suzan.hebditch@justice.gc.ca

Website: http://www.callacbd.ca/call.html

http://www.callacbd.ca/ip0a005e.html

Canadian Association of Law Libraries/Association canadienne des Bibliothèques de Droit (CALL/ACBD)

Annual General Meeting 2002

Victoria Conference Centre, Victoria, British Columbia, Canada

May 26-29, 2002

Website: http://www.callacbd.ca/call.html

http://www.callacbd.ca/ip0a005e.html

UK Centre for Legal Education, the Law Courseware Consortium and the British and Irish Legal Education Technology Association (BILETA)

SubTech 2002: Seventh International Conference on Substantive Technology in Legal Education

[see information on SubTech 2000, July 5-8, 2000, at http://ksgwww. harvard.edu/subtech2000/about.htm]

University of Warwick, England, UK

July 2002

Contact: Professor Abdul Paliwala, School of Law, University of Warwick, Coventry CV4 7AL, England, UK, Director, Law Courseware Consortium, Director C\&IT, UK Centre for Legal Education

Phone: +44 (0) 24765 23090; Fax: +44 (0) 2476524105

Website: http://www.law.warwick.ac.uk/

\section{American Association of Law Libraries (AALL)}

95 $5^{\text {th }}$ Annual Meeting

Orange County Convention Center, Orlando, Florida

July 20-24, 2002

Website: http://www.aallnet.org/events/

International Federation of Library Associations and Institutions (IFLA) $68^{\text {th }}$ IFLA Council and General Conference: "Libraries for Life: Democracy, Diversity, Delivery"

Glasgow, Scotland 
August 18-24, 2002

Website: http://www.ifla.org/IV/ifla68/index.htm

\section{3}

Canadian Association of Law Libraries/Association canadienne des Bibliothèques de Droit (CALL/ACBD)

Annual General Meeting 2003

May 2003

Toronto, Ontario, Canada

Website: http://www.callacbd.ca/call.html http://www.callacbd.ca/ip0a005e.html

\section{Nordic Law Librarians' Group 2003 Meeting}

Det 6. nordiske juridiske bibliotekmøte

[see information on 2000 meeting in Oslo, Norway at http://www.ub. uio.no/ujur/nordisk2000/]

Reykajavík, Iceland

Contact: Audur Gestdóttir, Landsbókasafn Íslands - Háskólabókasafn, National and University Library of Island, Arngrímsgata 3, IS107, Reykjavík, Iceland

Phone: + 3545255600

E-mail: audurg@bok.hi.is

Website: http://www.bok.hi.is/english/index.html

American Association of Law Libraries (AALL)

$96^{\text {th }}$ Annual Meeting

Washington State Convention \& Trade Center, Seattle, Washington

July $12-16,2003$

Website: http://www.aallnet.org/events/

International Federation of Library Associations and Institutions (IFLA) $69^{\text {th }}$ IFLA Council and General Conference: "Access Point Library Media Information - Culture"

Berlin, Germany

August 1-9, 2003

Website: $h t t p: / / w w w . i f l a . o r g / I V / i f l a 69 / 69 i n t r o . h t m$ 
Australian Library and Information Association (ALIA) Special Libraries Section and Health Libraries Section and Australian Law Librarians' Group (AALG)

$10^{\text {th }}$ Special, Health, and Law Libraries Conference [includes the biennial general meeting of the Australian Law Librarians' Group]

Adelaide, Australia

August 24-28, 2003

Website: http://www.alia.org.au/conferences/

http://www.allg.asn.au/ 